\title{
Production of Anchovy and Mussel Pastes as Appetizer
}

\author{
Berna Kilinc* and Volga Can Sahin \\ Fisheries Faculty, Fish Processing Technology Department, Ege University, Bornova-Izmir, Turkey
}

\begin{abstract}
Anchovy (Engraulis encrasicholus) is a species which mostly caught from Black sea by seine catch. This species represents the majority of the marine species consumed in Turkey. Mussel (Mytilus galloprovincialis) is a bivalve that has long been used as a marine food by boiling and stuffing with rice. It is harvested from Mediterranean, Aegean and Marmara sea and is mainly consumed in coastal towns. In this study, anchovy and mussel were used for raw materials. Subsequent to filleting the anchovy and extracting the meat of mussel, these two species were boiled in salty water and grinded. Ultimately, they were introduced separately to the mix of tomato paste, red pepper paste, swatted garlic, cumin, fenugreek powder, ground pepper, salt and olive oil. On account of its consistence, this developed product can be conserved in a paste tube as well as it can be bottled in a glass jar to preserve. The paste is suitable specially for use as appetizer in every repasts and can also be used as consistent intensifier and flavouring supplement during the cooking process. Aside from the production, the shelf life of the product was appointed by routine microbiological test methods (total aerobic mesophilic, psychrotrophic, coliform, Enterobactericeae, Micrococcus, Staphylococcus bacteria, yeast and moulds counts) and also the species of microorganisms found in pastes were identified. This is the first report about anchovy and mussel pastes describing microbiological flora.
\end{abstract}

\section{Keywords: Anchovy; Mussel; Paste; Shelf life; Microbiology}

\section{Practical Application}

This novel products promise an easy method to prepare appetizers from anchovy and mussel. It is quite possible to produce this in domestic environment, using only simple kitchen materials. The products can be considered as fairly convenient for working class families with their relatively long shelf life duration (6-7 weeks). Although well sanitized utensils and use of latex gloves are highly recommended to minimize human-induced contamination such as Staphylococcus spp. Within better environmental conditions and with less human impact, these products promise new aquatic food products for the food industry.

\section{Introduction}

Fish spoilage results from three basic mechanisms: Enzymatic autolysis, oxidation, microbial growth. Low temperature storage and chemical techniques for controlling water activity, enzymatic, oxidative and microbial spoilage are the most common in the industry today [1]. Spoilage of fresh and lightly preserved fish products is caused by microbial action. Shewanella putrefaciens and Pseudomonas spp. are the specific spoilage bacteria of iced fresh fish regardless of the origin of the fish. Modified atmosphere stored marine fish from temperate waters are spoiled by the $\mathrm{CO}_{2}$ resistant Photobacterium phosphoreum whereas Gram-positive bacteria are likely spoilers of $\mathrm{CO}_{2}$ packed fish from fresh or tropical waters. Fish products with high salt contents may spoil due to growth of halophilic bacteria (salted fish) or growth of anaerobic bacteria and yeasts (barrel salted fish). Whilst the spoilage of fresh and highly salted fish is well understood, much less is known about spoilage of lightly preserved fish products. It is concluded that the spoilage is probably caused by lactic acid bacteria, certain psychrotrophic Enterobacteriaceae and/or Photobacterium phosphoreum [2]. The suggested process would address antimicrobial activity as well as destructive oxidation of the desired lipids and fats. However, more efforts are required to understand the role of proximate composition of fish, post-harvest history, environmental conditions, initial microbial load, type and nature of bacteria and their interaction in order to optimize the shelf-life of fish. Proper handling, pre-treatment and preservation techniques can improve the quality fish and fish products and increase their shelf life [3]. Fermentation is one of the preservation techniques. Fermented fish have, for many years, been considered as a Southeast Asian product. These products are highly salted and fermented until the fish flesh is transformed into simpler components [4]. The potential for improving the nutritional quality and shortening the processing time necessary to produce these sauces could be realized by developing controlled microbial fermentations using pure cultures of the appropriate microorganisms. To identify what these are, it would be necessary to survey the microflora of different fish sauces and determine microbial successions [5].

There are many studies related to fish and fishery products in literature [4-12]. However, production of anchovy and mussel pastes as appetizer are novel products for literature. The aim of this study was to produce new fishery products from minced anchovy and mussel, as well as determining the microbiological flora of these pastes.

\section{Materials and Methods}

\section{Materials}

Materials that are used respectively to produce anchovy and mussel pastes as appetizer are;

Filleted raw anchovy meat (300 g)

Sorted raw mussel meat ( $300 \mathrm{~g})$

$2 \times$ Canned tomato paste $(250 \mathrm{~g})$

$2 \times$ Canned red pepper paste $(250 \mathrm{~g})$

$2 \times 15$ cloves of garlic (Allium cepa)

$2 \times$ Virgin olive oil $(75 \mathrm{ml})$

${ }^{*}$ Corresonding author: Berna Kilinc, Fisheries Faculty, Fish Processing Technology Department, Ege University, Bornova-Izmir, Turkey, Tel: +902323111010; E-mail: berna.kilinc@ege.edu.tr

Received September 16, 2015; Accepted October 06, 2015; Published October 15,2015

Citation: Kilinc B, Sahin VC (2015) Production of Anchovy and Mussel Pastes as Appetizer. J Food Process Technol 6: 516. doi:10.4172/2157-7110.1000516

Copyright: ( $) 2015$ Kilinc B, et al. This is an open-access article distributed under the terms of the Creative Commons Attribution License, which permits unrestricted use, distribution, and reproduction in any medium, provided the original author and source are credited. 
$2 \times$ Common salt ( 1 teaspoon)

$2 \times$ Flaked red pepper ( 1 teaspoon)

$2 \times$ Black pepper (1 teaspoon)

$2 \times$ Cummin powder ( 2 teaspoons)

$2 \times$ Fenugreek powder (25 grams)

Ingredients composition is shown at Table 1 as percentages.

\section{Methods}

Production of minced anchovy and mussel: The process of producing anchovy and mussel pastes has not been conducted in an aseptic laboratory, instead, a regular kitchen has been used to prepare and mix the ingredients. The purpose was to see the shelf life of these products in refrigerated conditions $\left(+4^{\circ} \mathrm{C}\right)$ when processed by ordinary people in domestic environment. None of the equipment that used to prepare the anchovy and mussel pastes were sterilized, whilst they were sanitized by commercial cleansings. For the supply of raw anchovy and mussel meat (already sorted, ready to process), a regular wholesale market hall is used. Subsequent to filleting operation of anchovy, the meat of mussel and boneless anchovy were boiled in preheated, distilled, salty (4\%) water for 5 minutes. Afterwards, the fish and mussel meats were minced by a knife separately. The ultimate weight of boiled and minced meats was $300 \pm 10$ grams each.

Production of paste: On this phase, two separated paste mixtures were prepared using exactly the same amounts of ingredients on the same conditions. Each one of them includes $250 \pm 10$ grams of canned tomato paste, $250 \pm 10$ grams of canned red pepper paste, 15 smashed cloves of garlic (70 grams), $75 \mathrm{ml}$ of ordinary virgin olive oil, a teaspoon of common salt, a teaspoon of flaked red pepper, two teaspoon of cumin powder, a teaspoon of black pepper and $20 \mathrm{ml}$ of fenugreek powder. All these ingredients were introduced into a big bowl to homogenize after the meats were added. Ultimately, the anchovy paste and the mussel paste were build (950 \pm 50 grams each).

Refrigerated storage of finished products: Petri dishes were selected as container to piling the final products in the refrigerator. Approximately 12-20 grams of each paste were placed in petri dishes in aseptic environment. Once all the pastes were placed in petri dishes, they were stocked in the refrigerator to be used only for microbiological controls on a regular basis.

Microbiological analysis: Ten grams of anchovy and mussel pastes were homogenized in $90 \mathrm{ml}$ of peptone water separately. Other decimal dilutions were prepared from them. Anchovy and mussel pastes were homogenized in a stomacher (IUL, Barcelona, Spain) for 1 minute. Total mesophilic and psychrotrophic bacteria counts analysis was made by using pour plate method. Plate Count Agar (PCA, Oxoid, CM0325) was used for these analysis. Inoculated petri dishes were incubated 48 hours at $30^{\circ} \mathrm{C}$ for total mesophilic bacteria count [13] and 14 days at $4^{\circ} \mathrm{C}$ for psychrotrophic bacteria count [14]. For determining yeast and mould counts; Yeast Extract Glucose Chloromphenicol Agar (YGC, Merck) was used. Inoculated petri dishes were incubated 5 days at $25^{\circ} \mathrm{C}$ [15]. Enterobactericeae analyse was done by using Violet Red Bile Glucose Agar (VRBD, Merck) according to the method of Vanderzant and Splittstoesser [16]. Inoculated petri dishes were incubated 24 hours at $37^{\circ} \mathrm{C}$. Violet Red Bile Agar (VRB, LABM, LAB031) was used for determining coliform bacteria count. Inoculated petri dishes were incubated 24 hours at $30-32^{\circ} \mathrm{C}$ according to the method of DeMan et al. [15]. Staphylococcus bacteria count analyse was done by using Baird
Parker Agar (BPA, Merck). Inoculated petri dishes were incubated 30 hours at $37^{\circ} \mathrm{C}$ [16]. For determining Micrococcus bacteria count; Mannitol Salt Phenol Red Agar (MSPRA, Merck) was used. Inoculated petri dishes were incubated 48 hours at $30^{\circ} \mathrm{C}$ [17].

Bacterial identification: The isolated all bacteria species were identified according to method of API system (biomerieux, France). Isolated Micrococcus bacteria was identified by using API E, isolated yeast and mould counts were identified by using API CAUX. Staphylococcus bacteria count was identified by using API Staph test kits.

Statistical analyses: SPSS version 11 statistical package program for social science was used for statistical analyses of anchovy and mussel pastes. One-way analysis of variance was done for determining significant differences with groups. No significant differences indicated as $(\mathrm{p}>0.05)$. Significant differences indicated as $(\mathrm{p}<0.05)$.

\section{Results and Discussion}

\section{Microbiological analysis}

Microbiological changes of anchovy and mussel pastes are shown in Table 2. Enumeration of total mesophilic bacteria load of pastes showed that bacteria levels increased during fermentation period. Numbers of total mesophilic bacteria in the anchovy pastes ranged from $4.48 \mathrm{log}$ $\mathrm{cfu} / \mathrm{g}$ to $6.92 \mathrm{log} \mathrm{cfu} / \mathrm{g}$ after 8 weeks of fermentation. Total mesophilic bacteria count of mussel pastes increased from $4.86 \mathrm{log} \mathrm{cfu} / \mathrm{g}$ to 6.89 $\log \mathrm{cfu} / \mathrm{g}$ at the end of 8 weeks. No significant $(\mathrm{p}<0.05)$ changes in total mesophilic bacteria counts between the groups occurred during fermentation. But according to time of fermentation, these differences were significant $(p>0.05)$ for two groups. Psychrotrophic bacteria counts were determined after 6 weeks of fermentation. On week 8; psychrotrophic bacteria count increased to $4.78 \mathrm{log} \mathrm{cfu} / \mathrm{g}$ and $4.66 \mathrm{log}$ $\mathrm{cfu} / \mathrm{g}$ for anchovy and mussel pastes, respectively. Enterobactericeae and coliform bacteria could not be isolated throughout the period of fermentation for two groups due to slowing-down effect on microbiological growth of chopped garlic depending on the garlic concentration, along with some other spices such as black and red pepper $[18,19]$. Yeast and mould counts of anchovy and mussel pastes ranged between $2.58 \log \mathrm{cfu} / \mathrm{g}$ (week 2 , anchovy paste) and $1>\log \mathrm{cfu} / \mathrm{g}$. No harmful growth $(\mathrm{p}<0.05)$ was detected for yeast and mould count during the fermentation for both products. The reason why there was no excessive yeast and mould growth is similar with the reason why there was no Enterobactericeae and coliform bacteria growth; it is due to the inhibiting effect of garlic [20]. Micrococcus spp. growth showed little difference in terms of storage. It started with $4.28 \mathrm{log} \mathrm{cfu} / \mathrm{g}$ for anchovy paste and $5.00 \mathrm{log} \mathrm{cfu} / \mathrm{g}$ for mussel paste on first week. On the week 8; the numbers were not much different; $5.04 \mathrm{log} \mathrm{cfu} / \mathrm{g}$ for anchovy paste and $5.48 \mathrm{log} \mathrm{cfu} / \mathrm{g}$ for mussel paste. Staphylococcus spp. counts showed fairly little difference for either weeks and groups of anchovy and mussel pastes. On the first week; $4.02 \mathrm{cfu} / \mathrm{g}$ for anchovy paste and $3.99 \mathrm{cfu} / \mathrm{g}$ for mussel paste. For the 8th week; the Staphylococcus spp. loads were $4.52 \mathrm{cfu} / \mathrm{g}$ and $4.74 \mathrm{cfu} / \mathrm{g}$ for anchovy and mussel pastes, respectively. Although Staphylococcus spp. are commonly found in most kinds of food, they are not in natural microflora of aquatic species. It is only possible to find Staphylococcus spp. in aquatic products when there is human impact or there is a non-aquatic food supplementation [9]. Therefore, it is recommended to produce this kind of products in more sanitized conditions and with less human impact.

Findings of a study about the pastramis which were prepared experimentally have been mixed with the various cemen pastes are 
Citation: Kilinc B, Sahin VC (2015) Production of Anchovy and Mussel Pastes as Appetizer. J Food Process Technol 6: 516. doi:10.4172/21577110.1000516

Page 3 of 4

\begin{tabular}{|c|c|c|c|c|c|c|}
\hline & \multicolumn{6}{|c|}{ Percentage } \\
\hline & $30 \%$ & $25 \%$ & $7 \%$ & $2,5 \%$ & $1 \%$ & $<1 \%$ \\
\hline \multirow[t]{3}{*}{ Materials } & -Meat & -Tomato pure & -Garlic & ○Fenugreek powder & -Cummin powder & -Common salt \\
\hline & & -Red pepper pure & -Virgin olive oil & & & -Black pepper \\
\hline & & & & & & -Flaked red pepper \\
\hline
\end{tabular}

Materials on the same column indicates same amount of percentage in products

Table 1: The percentages of Ingredients for both products

\begin{tabular}{|c|c|c|c|c|c|c|c|c|}
\hline \multicolumn{9}{|c|}{ Microorganism Types } \\
\hline $\begin{array}{l}\text { Storage } \\
\text { (Week) }\end{array}$ & Groups & $\begin{array}{l}\text { Total Mesophilic } \\
\text { Bacteria Count } \\
\text { (log cfu/g) }\end{array}$ & $\begin{array}{l}\text { Micrococcus } \\
\text { Bacteria Count } \\
(\log \mathrm{cfu} / \mathrm{g})\end{array}$ & $\begin{array}{l}\text { Staphylococcus } \\
\text { Bacteria Count } \\
\text { (log cfu/g) }\end{array}$ & $\begin{array}{l}\text { Yeast \& Mould } \\
\text { Counts } \\
(\log \mathrm{cfu} / \mathrm{g})\end{array}$ & $\begin{array}{l}\text { Psychrotrophic } \\
\text { Bacteria Count } \\
\text { (log cfu/g) }\end{array}$ & $\begin{array}{l}\text { Coliform } \\
\text { Bacteria Count } \\
\text { (log cfu/g) }\end{array}$ & $\begin{array}{l}\text { Enterobacteriaceae } \\
\text { BacteriaCount } \\
\text { (logcfu/g) }\end{array}$ \\
\hline \multirow{2}{*}{1.} & A & $4.48 \pm 0.04^{\mathrm{aA}}$ & $4.28 \pm 0.04^{\mathrm{bA}}$ & $4.02 \pm 0.14^{\mathrm{aA}}$ & $<1^{\mathrm{bA}}$ & $<1^{\mathrm{aA}}$ & $<1^{\mathrm{aA}}$ & $<1^{\mathrm{aA}}$ \\
\hline & M & $4.86 \pm 0.52^{\mathrm{aA}}$ & $5.00 \pm 0.15^{\mathrm{aA}}$ & $3.99 \pm 0.10^{\mathrm{aA}}$ & $1.89 \pm 0.11^{\mathrm{aA}}$ & $<1^{\mathrm{aA}}$ & $<1^{\mathrm{aA}}$ & $<1^{\mathrm{aA}}$ \\
\hline \multirow{2}{*}{2.} & A & $5.26 \pm 0.40^{\mathrm{aB}}$ & $4.74 \pm 0.06^{\mathrm{aA}}$ & $4.20 \pm 0.06^{\mathrm{aA}}$ & $2.58 \pm 0.19^{\mathrm{aB}}$ & $<1^{\mathrm{aA}}$ & $<1^{\mathrm{aA}}$ & $<1^{\mathrm{aA}}$ \\
\hline & M & $5.32 \pm 0.08^{\mathrm{aA}}$ & $5.00 \pm 0.11^{\mathrm{aA}}$ & $4.02 \pm 0.05^{\mathrm{aA}}$ & $2.02 \pm 0.70^{\mathrm{bA}}$ & $<1^{\mathrm{aA}}$ & $<1^{\mathrm{aA}}$ & $<1^{\mathrm{aA}}$ \\
\hline \multirow{2}{*}{3.} & A & $5.17 \pm 0.05^{\mathrm{aB}}$ & $5.28 \pm 0.10^{\mathrm{aB}}$ & $4.43 \pm 0.06^{\mathrm{aA}}$ & $<1^{\mathrm{bA}}$ & $<1^{\mathrm{aA}}$ & $<1^{\mathrm{aA}}$ & $<1^{\mathrm{aA}}$ \\
\hline & M & $5.33 \pm 0.11^{\mathrm{aA}}$ & $5.32 \pm 0.16^{\mathrm{aA}}$ & $3.96 \pm 0.17^{\mathrm{aA}}$ & $1.35 \pm 0.37^{\mathrm{aA}}$ & $<1^{\mathrm{aA}}$ & $<1^{\mathrm{aA}}$ & $<1^{\mathrm{aA}}$ \\
\hline \multirow{2}{*}{4.} & A & $5.42 \pm 0.05^{\mathrm{aB}}$ & $4.78 \pm 0.02^{\mathrm{aB}}$ & $4.21 \pm 0.04^{\mathrm{aA}}$ & $<1^{\mathrm{aA}}$ & $<1^{\mathrm{aA}}$ & $<1^{\mathrm{aA}}$ & $<1^{\mathrm{aA}}$ \\
\hline & $M$ & $5.44 \pm 0.04^{\mathrm{aB}}$ & $5.13 \pm 0.10^{\mathrm{aA}}$ & $3.96 \pm 0.16^{\mathrm{aA}}$ & $<1^{\mathrm{aA}}$ & $<1^{\mathrm{aA}}$ & $<1^{\mathrm{aA}}$ & $<1^{\mathrm{aA}}$ \\
\hline \multirow{2}{*}{5.} & A & $5.40 \pm 0.07^{\mathrm{aB}}$ & $4.97 \pm 0.04^{\mathrm{aB}}$ & $4.56 \pm 0.04^{\mathrm{aB}}$ & $1.56 \pm 0.07^{\mathrm{aB}}$ & $<1^{\mathrm{aA}}$ & $<1^{\mathrm{aA}}$ & $<1^{\mathrm{aA}}$ \\
\hline & M & $5.55 \pm 0.14^{\mathrm{aB}}$ & $5.06 \pm 0.09^{\mathrm{aA}}$ & $4.34 \pm 0.07^{\mathrm{aA}}$ & $1.35 \pm 0.37^{\mathrm{aA}}$ & $<1^{\mathrm{aA}}$ & $<1^{\mathrm{aA}}$ & $<1^{\mathrm{aA}}$ \\
\hline \multirow{2}{*}{6.} & A & $5.10 \pm 0.62^{\mathrm{bB}}$ & $4.96 \pm 0.05^{\mathrm{aB}}$ & $4.64 \pm 0.13^{\mathrm{aB}}$ & $<1^{\mathrm{aA}}$ & $4.48 \pm 0.07^{\mathrm{aB}}$ & $<1^{\mathrm{aA}}$ & $<1^{\mathrm{aA}}$ \\
\hline & M & $5.83 \pm 0.07^{\mathrm{ac}}$ & $5.11 \pm 0.07^{\mathrm{aA}}$ & $4.44 \pm 0.06^{\mathrm{aA}}$ & $1.39 \pm 0.55^{\mathrm{aA}}$ & $4.39 \pm 0.15^{\mathrm{aB}}$ & $<1^{\mathrm{aA}}$ & $<1^{\mathrm{aA}}$ \\
\hline \multirow{2}{*}{7.} & A & $5.69 \pm 0.10^{\mathrm{bc}}$ & $5.11 \pm 0.06^{\mathrm{aB}}$ & $5.65 \pm 0.16^{\mathrm{aB}}$ & $<1^{\mathrm{aA}}$ & $4.64 \pm 0.15^{\mathrm{aB}}$ & $<1^{\mathrm{aA}}$ & $<1^{\mathrm{aA}}$ \\
\hline & M & $6.29 \pm 0.12^{\mathrm{ac}}$ & $5.41 \pm 0.51^{\mathrm{aA}}$ & $4.44 \pm 0.11^{\mathrm{aA}}$ & $1.36 \pm 0.39^{\mathrm{aA}}$ & $4.65 \pm 0.05^{\mathrm{aB}}$ & $<1^{\mathrm{aA}}$ & $<1^{\mathrm{aA}}$ \\
\hline \multirow{2}{*}{8.} & A & $6.92 \pm 0.04^{\mathrm{aD}}$ & $5.04 \pm 0.16^{\mathrm{aB}}$ & $4.52 \pm 0.08^{\mathrm{aA}}$ & $1.20 \pm 0.17^{\mathrm{aA}}$ & $4.78 \pm 0.05^{\mathrm{aB}}$ & $<1^{\mathrm{aA}}$ & $<1^{\mathrm{aA}}$ \\
\hline & M & $6.89 \pm 0.11^{\mathrm{aD}}$ & $5.48 \pm 0.22^{\mathrm{aA}}$ & $4.74 \pm 0.17^{\mathrm{aB}}$ & $1.42 \pm 0.48^{\mathrm{aA}}$ & $4.66 \pm 0.06^{\mathrm{aB}}$ & $<1^{\mathrm{aA}}$ & $<1^{\mathrm{aA}}$ \\
\hline
\end{tabular}

A stands for anchovy paste $M$ stands for mussel paste

Different capital letters (A,B,C,D) stand for significant differences $(p>0.05)$ dependent on storage

Different small letters $(a, b)$ stand for significant differences $(p>0.05)$ between groups for each week

Table 2: Microbiological changes of anchovy and mussel pastes.

shown [21]. The count of total microorganisms was between $2.8 \times 10^{7}$ and $7.0 \times 10^{7} / \mathrm{g}$ on the first day, and between $2.2 \times 10^{6}-3.4 \times 10^{6} / \mathrm{g}$ on the 60 th day. The number of yeast was between $8.2 \times 10^{4}$ and $1.4 \times 10^{7} / \mathrm{g}$ on the first day, and between $3.8 \times 10^{3}$ and $1.2 \times 10^{4} / \mathrm{g}$ on the 60th day. The number of mould was between $1.2 \times 10^{6}$ and $2.5 \times 10^{6} / \mathrm{g}$ on the first day, and between $7.6 \times 10^{4}$ and $5.8 \times 10^{8} / \mathrm{g}$ on the 60 th day. The number of Staphylococcus-Micrococcus microorganisms was between $5.1 \times 10^{6}$ $2.1 \times 10^{8} / \mathrm{g}$ on the first day, and between $1.4 \times 10^{5}$ and $3.9 \times 10^{5} / \mathrm{g}$ on the 60th day. Enterobactericeae microorganisms were not cultivated in all phases of first stage of pastramis samples. Similar results were determined with this study about inhibiting Enterobactericeae. Another study about production of sardine fermented fish sauce was done by Kilinc [8]. In this study, authors reported that the fish sauces with spices were determined lower bacteria counts than fish sauces without spices. Staphylococcus aureus and yeast-mould counts were not detected during fermentation period. The use of spices in fermentation of sardine enhanced good colour, aroma and taste. Verluyten et al. [22] studied the effect of different spices relevant for the production of fermented sausages. In this study; addition of spices to the sausage mixture is clearly a factor that will influence the effectiveness of bacteriocinogenic starter cultures in fermented-sausage manufacturing. In another study, Microorganisms involved in the natural fermentation of Sardinella sp. were enumerated and characterized. Total heterotrophic bacterial counts obtained after six days of fermentation were $6.23 \times 10^{5} \mathrm{cfu} / \mathrm{g}$ and $5.65 \times 10^{5} \mathrm{cfu} / \mathrm{g}$ for fish treated with 10 and $15 \%(\mathrm{w} / \mathrm{v})$ sodium chloride, respectively. Staphylococcus species were the predominant organisms isolated from the fermenting fish [5]. Similar results were determined about high number of Staphylococcus species found in pastes with this investigation. Lactic acid fermented fish were done by using sardine (Sardina pilchardus) and anchovy (Engraulis engrasicholus). In this study it was determined that only lactic acid, only lactic acid bacteria or lactic acid and lactic acid bacteria together can be used for extending the shelf-life of fish products [23]. Tayar [11] studied the effect of various heating processes on Turkish sausages. This author reported that from microbiological point of view during the heat treatment in which core temperature was $62^{\circ} \mathrm{C}$, coliform bacteria was destroyed and in important decline in the total bacteria counts were observed.

According to Turkish Food Codex [24]; for fermented meat products, mould counts must not exceed the limiting value of 3.0 $\mathrm{cfu} / \mathrm{g}$ and Staphylococcus aureus must be limited to $3.0 \mathrm{cfu} / \mathrm{g}$. There is no specific limitation for total aerobic mesophilic bacterial load for fermented meat derivatives. However, the limit value for total aerobic mesophilic bacterial load of refrigerated meat products is $6.0 \mathrm{log} \mathrm{cfu} / \mathrm{g}$. In our products, upper limits for yeast and mould count was $2.58 \mathrm{cfu} / \mathrm{g}$ for anchovy paste (on second week) and $2.02 \mathrm{log} \mathrm{cfu} / \mathrm{g}$ for mussel paste (on second week). Amongst the Staphylococcus spp. isolates of our products, no Stahphylococcus aureus were detected. As for the total mesophilic bacteria count, while the anchovy paste was due on the 8th week, the due date of mussel paste was found as $7^{\text {th }}$ week. On week 7 ; total mesophilic bacteria counts for anchovy paste was $5.69 \mathrm{log} \mathrm{cfu} / \mathrm{g}$ and for mussel paste, it was $6.29 \log \mathrm{cfu} / \mathrm{g}$. On week 8; this counts were $6.29 \mathrm{log}$ $\mathrm{cfu} / \mathrm{g}$ and $6.89 \mathrm{log} \mathrm{cfu} / \mathrm{g}$ for anchovy paste and mussel paste, respectively.

\section{Bacterial identification}

In this study, identified bacteria species showed no difference 
depending on groups. Identified bacteria species and ratios were the same for both anchovy and mussel pastes. For Enterobactericeae spp., only determined bacteria species was Erwinia spp with a ratio of $80 \%$. Staphylococcus bacteria species were determined as Staphylococcus sciuri and Staphylococcus auricularis with $49.9 \%$ and $42.9 \%$ ratios, respectively. For the yeasts and moulds identification, determined species throughout the fermentation are identified as Cryptococcus spp. with a ratio of $80 \%$, Cryptococcus humicola with a ratio of $68.8 \%$ and Trichosporon mucoides with a ratio of $30.8 \%$.

Kuda et al. [25] studied fish nukazuke is salted and long-fermented fish with rice bran. Histamine $(\mathrm{Hm})$ forming bacteria were isolated from fish nukazuke. They screened bacteria that can inhibit the $\mathrm{Hm}$ forming (Hm suppressive) bacteria. Both of the isolates were identified to Tetragenococcus halophilus. Paluda Müller et al. [26] reported that Thai fermented fish product prepared from snakehead fish, salt, palm syrup and roasted rice. In fermented fish product $95 \%$ of the yeasts as Zygosaccharo mycesrouxii was identified as well as lactic acid bacteria. Jeotgal or jeot, a traditional Korean salted and fermented food, is made by adding $20-30 \%$ (w/w) salt to various types of sea food worked by Guan et al. [27]. Eleven genera were isolated from both jeotgal samples, including species in the genera Staphylococcus, Bacillus, Halomonas, and Kocuria, with Staphylococcus spp. constituting the highest number. Staphylococcus spp. may not be hugely involved in proteolysis, but they may play a significant role in the ripening of jeotgal. Bacteria of the genus Bacillus and its relative sand of the genus Staphylococcus may be the major organisms involved in jeotgal fermentation. These studies show resemblance with our study in terms of Staphylococcus spp. and yeast loads.

\section{Conclusion}

In this study, shelf life of anchovy paste was detected as 7 weeks, whereas the shelf life of mussel paste was detected as 6 weeks according to microbiological analysis. Bacteria species identification showed resemblance for both products. Identified bacteria species were; Erwinia spp., Staphylococcus spp., Cryptococcus spp. and Trichosporon spp. Anchovy and mussel pastes are new products for literature. This is the first report about anchovy and mussel pastes describing microbiological flora and shelf life. For this reason, the results of this study will be very helpful for food industry and readers.

\section{References}

1. Ghaly AE, Dave D, Budge S, Brooks MS (2010) Fish spoilage mechanisms and preservation techniques: review. American Journal of Applied Sciences 7: 859-877.

2. Gram L, Huss HH (1996) Microbiological spoilage of fish and fish products. International Journal of Food Microbiology 33: 121-137.

3. Huss HH, Valdimarsson $\mathrm{G}$ (1990) Microbiology of salted fish. FAO Fish Tech News 10: 3-5.

4. Crisan EV, Sands A (1974) Microflora of four fermented fish sauces. Applied Microbiology 29: 106-108.

5. Achinewhu SC, Amadi EN, Barimalaa IS, Eke J (2008) Microbiology of naturally fermented fish (Sardinella $\mathrm{sp}$ ). Journal of Aquatic Food Product Technology 35: 47-53.

6. Ganjavi M, Ezzatpanah H, Givianrad MH, Shams A (2010) Effect of canned tuna fish processing steps on lead and cadmium contents of Iranian tuna fish. Food Chemistry 118: 525-528.

7. Gokoglu N, Topuz OK, Yerlikaya P (2009) Effects of pomegranate sauce on quality of marinated achovy during refrigerated storage. LWT - Food Science and Technology 42: 113-118.

8. Kılınç B, Çaklı Ş, Tolasave Ş, Dinçer T (2006) Chemical, microbiological and sensory changes associated with fish sauce processing. European Food Research and Technology 222: 604-613.

9. Patir B, Oksuztepe G, Çoban OE, Dikici A. (2009) The shelf life of frozen shrimp prepared from meat croquettes. F. Health Sciences Veterinary Journal 23: 29-37.

10. Siriskar DA, Khedkar GD, Lior D (2013) Production of salted and pressed anchovies (stolephorus sp.) and it's quality evaluation during storage. Journal of Science and Technology 50: 1172-1178.

11. Tayar M (1994) The effect of various heating processes on turkish sausages Gida 19: 117-21.

12. Topuz Ok, Yerlikaya P, Ucak I, Gumus B, Buyukbenli HA, et al. (2014) Effects of olive oil and olive oil-pomegranate juice sauces on chemical, oxidative and sensorial quality of marinated anchovy. Food Chemistry 154: 63-70.

13. ICMSF (1986) Microorganisms in foods: 2. Sampling or Microbiological Analysis Principles and Specific Applications. Bendig J (2nd edn), University of Toronto Press, Toronto, Ontario. 20: 456-457.

14. Merck (1998) Food microbiology. My ORK chemicals tic. Itd.

15. DeMan JC, Ragosa M, Sharpe ME (1960) A Medium for cultivation of lactobacilli. J of App. Bacteriology 23: 130-135.

16. Vanderzant C, Splittstoesser DF (1992) Compendium of methods for the microbiological examination of foods. (3rd edn), Washington DC, American Public Health Association.

17. Mossel DA, Moreno Garcia B (1985) Food Microbiology. Acribiai, Zaragoza, Spain: 214-272.

18. Aydin A, Bostan K, Erkan ME, Bingöl B (2007) The antimicrobial effects of chopped garlic in ground beef and raw meatball. Journal of Medicinal Food 10: 203-207.

19. Zarringhlam M, Zaringhalan J, Shadnous M, Safaeyan F, Tekieh E, et al. (2013) Inhibitory effect of black and red pepper and thyme extracts and essential oils on enterohemorrhagic Escherichia coli and dnase activity of Staphylococcus aureus. Iranian Journal of Pharmaceutical Research 12: 363-369.

20. Kocic-Tanackov S, Dimic G, Levic J, Tanackov I, Tepic A, et al. (2012) Effects of onion (Allium cepa L.) and garlic (Allium sativum L.) essential oils on the Aspergillus versicolor growth and sterigmatocystin production. Journal of Food Science 77: M278-284.

21. Doğruer Y, Nizamlıoğlu M, Gürbüz Ü, Kayaardı S (1998) The effects of various cemen mixtures on the quality of pastrami II: Microbiological Quality. Tr. J. of Veterinary and Animal Sciences 22: 221-229.

22. Verluyten J, Leroy F, Vuyst L (2004) Effects of different spices used in production of fermented sausages on growth of and curvacin a production by lactobacillus curvatus LTH: 1174 . Applied and Environmental Microbiology 70 : 4807-4813.

23. Kılınç B, Çaklı Ş (2011) Lactic acid fermentation with sardine (Sardina pilchardus) and anchovy (Engraulis encrasicholus) products produced from fermented fish species. $16^{\text {th }}$ National Fisheries Symposium, Istanbul.

24. http://www.saglik.gov.tr/HM/dosya/1-73807/h/turk-gida-kodeksi-mikrobiyolojikkriterler-tebligi-ve-d-.doc

25. Kuda T, Izawa Y, Ishii S, Takahashi H, Torido Y, et al. (2012) Suppressive effect of Tetragenococcus halophilus isolated from fish nukazuke on histamine accumulation in salted and fermented fish. Food Chemistry 130: 569-574.

26. Paludan-Müller $C$, Madsen $M$, Sophanodora $P$, Gram L, LangeMøller $P$, et al. (2002) Fermentation and microflora of plaa-som, Thai fermented fish product prepared with different salt concentrations. International Journal of Food Microbiology 73: 61-70.

27. Guan L, Cho KH, Jong-Hoon L (2011) Analysis of cultivable bacterial community in jeotgal, a Korean salted and fermented sea food and identification of its dominant bacteria. Food Microbiology 28: 101-113. 